\title{
Los ángeles músicos. Estudio de los tipos iconográficos de la narración evangélica
}

\author{
Candela Perpiñ́ García \\ Universitat de València. \\ Departamento de Historia del Arte. Programa FPU del MEC.
}

\begin{abstract}
RESUMEN
El presente artículo pretende ofrecer una nueva vía de análisis de las imágenes musicales a través del estudio de los tipos iconográficos y las fuentes literarias e icónicas que los configuran. En este caso se ha optado por realizar un estudio del tipo del ángel músico en la narración evangélica y las razones de su inclusión en los diferentes tipos narrativos del arte visual cristiano.
\end{abstract}

Palabras clave: Iconografía musical, ángeles músicos, natividad, ascensión, asunción y coronación de la Virgen.

\section{Musician angels. Study of the narrative evangelic iconographic types}

\begin{abstract}
The aim of this article is to offer a new way to analyse musical images trough the study of iconographic types and their literary and iconic sources. More precisely, this paper focuses on the apparition of the musician angel in the narrative evangelic context and the reasons for its inclusion in the various narrative types of Christian visual art.
\end{abstract}

Keywords: Musical iconography, musician angel, nativity, ascension, assumption and crowning of Mary.

Este trabajo se halla inscrito en el Proyecto de Investigación $\mathrm{I}+\mathrm{D}+\mathrm{i}$ Los tipos iconográficos. Descripción diacrónica, que actualmente está siendo llevado a cabo por el Grupo APES del Departamento de Historia del Arte de la Universidad de Valencia ${ }^{1}$. El proyecto tiene como objetivo el análisis de los tipos iconográficos del arte visual cristiano desde una perspectiva universal, si bien atendiendo especialmente a aquellos desarrollados en el ámbito hispánico - español e iberoamericano $^{2}$. Su estructura se inspira fundamentalmente - no exhaustivamente- en

\footnotetext{
1 Ministerio de Ciencia e Innovación. Ref.: HAR 2008-04437. Investigador principal: Dr. Rafael García Mahíques, Universitat de València.

2 Para más información vid. GARCÍA MAHÍQUES, Rafael, “El proyecto 'Los tipos iconográficos' y una reflexión sobre la terminología en los estudios iconográficos”, en Id. y ZURIAGA SENENT, Vicent F.
} 
el sistema Iconclass, y tiene como objetivo ofrecer de forma analítica la estructura diacrónica de los diferentes tipos iconográficos con el fin de poder establecer una plataforma de referencia fundamental para cualquier estudio dentro de la Historia del arte planteada desde el enfoque iconográfico-iconológico. Uno de los pilares de este proyecto es la distinción entre tema y tipo iconográfico. Mientras el tema es algo conceptual y abstracto, extra-artístico, el tipo es "lo concreto en que se traduce o se hace sensible el tema en el ámbito artístico [...] el modo concreto como el tema se establece en imagen -o en sucesión de imágenes" ${ }^{\text {. }}$ El tipo correspondería a la manifestación plástica o la visualización de un concepto mediante un determinado esquema compositivo que finamente llega a formar parte de la tradición cultural común de una sociedad ${ }^{4}$. El tipo iconográfico es, pues, un concepto que se ciñe estrictamente a la imagen gráfica o física, mientras que el término imagen abarca un amplio espectro de manifestaciones, de las cuales las más importantes para nuestro cometido son: la gráfica, la literaria y la mental $1^{5}$. Los tipos pueden ser "conceptuales" y "narrativos", en función de cómo se establezcan las coordenadas espacio-temporales en su representación ${ }^{6}$. Cabe tener en cuenta, además, su carácter mutable ya que, a lo largo del tiempo y debido a las nuevas necesidades culturales, van conociendo un número de variantes que llegan a instituirse a su vez como otros tantos tipos iconográficos de igual interés cultural ${ }^{7}$, conformando un esquema arbóreo de creciente complejidad que bien puede observarse en el sistema Iconclass. Asimismo, a la hora de interpretar la imagen, es preciso distinguir entre la posible intención original y el conjunto de significados que adquiere en virtud de la mirada y de las interpretaciones posteriores. Todo ello da lugar a una compleja vida de las imágenes, sujetas éstas a un proceso de continuidad y variación, cuya verificación es lo que realmente conforma la historia de los tipos iconográficos, algo indispensable como referente desde el cual poder plantear una Historia cultural, objeto de la Iconología como modo de articular la Historia del arte.

Debido a sus especiales características, este método de análisis puede ser aplicado a cualquier imagen que se desee estudiar desde el punto de vista iconográfico, e incluso posibilita la introducción de aspectos interdisciplinares como parte de dicho análisis. En este artículo expondremos el caso concreto del estudio de

(eds.), Imagen y Cultura. La interpretación de las imágenes como Historia cultural, vol. I, Valencia, Biblioteca Valenciana, 2008, pp. 21-42.

GARCÍA MAHÍQUES, Rafael, Iconografía e iconología, vol. 2, Madrid, Encuentro, 2009, pp. 38-40.

Para la distinción entre tema, tipo y tradición cultural vid. Ibid., pp. 38-40 503-537.

MITCHELL, William J Thomas, "What Is an image", en New Literary History, 14, n 3, 1984, pp.

6 GARCÍA MAHÍQUES, Rafael, “Imagen conceptual e imagen narrativa”, en Emblemática trascendente. Hermenéutica de la imagen, iconología del texto, Actas del VII Congreso Internacional de Emblemática (Pamplona, 9-11 de diciembre de 2009), de próxima publicación.

7 Id. (2009), op. cit., p. 38. 
las imágenes con representaciones musicales o iconografía musical. La iconografía musical es una materia interdisciplinar actualmente inscrita en el ámbito de la Musicología que pone al servicio del análisis iconográfico-iconológico un bagaje de conocimientos musicales previos sin los cuales gran parte del significado de la imagen quedaría oculto. Si bien en sus inicios la iconografía musical abordaba el estudio de las imágenes principalmente desde la organología buscando paralelismos con la realidad musical histórica, hoy en día se está abriendo una nueva tendencia que toma en consideración la riqueza de contenidos que, más allá del análisis puramente organológico, estas imágenes ofrecen ${ }^{8}$. Gran parte de estos esfuerzos se deben al RIdIM (Repértoire Internacional d'Iconographie Musicale) y a los grupos de investigación ligados a esta institución que desde su creación en 1970 tiene como principal objetivo la catalogación de imágenes musicales ${ }^{9}$. El Proyecto Los tipos iconográficos. Descripción diacrónica ofrece una novedosa metodología a través de la cual las imágenes con representaciones musicales del arte visual cristiano pueden estudiarse según temas y tipos, siguiendo los pasos del análisis iconográfico-iconológico y con una especial atención a la configuración de los mismos bien sea a nivel de imagen plástica, literaria, o sencillamente mental. Por ello es fundamental acudir a las fuentes, literarias o gráficas, que conservamos en la actualidad y observar las relaciones que se establecen. En este artículo nos centraremos en la figura del ángel músico, el tipo iconográfico que con mayor frecuencia visualiza el concepto de música celestial. Se trata, por tanto, de un tipo conceptual que se desarrolla, de manera prácticamente paralela, por la vía conceptual y la vía narrativa, y que a su vez es susceptible de ser incluido en otros tipos conceptuales o narrativos debido a las fuentes literarias o, simplemente, a la tradición visual preexistente. El estudio del ángel músico en la narración evangélica es un excelente ejemplo del proceso de configuración de los tipos y de las relaciones que se establecen entre texto e imagen en dicho proceso. En el presente artículo trataremos brevemente los temas y tipos narrativos que con mayor frecuencia incluyen su presencia.

La primera mención inequívoca de la música angélica la hallamos en uno de los llamados apócrifos de la natividad. Se trata del Evangelio del Pseudo Mateo (mediados del s. VI) ${ }^{10}$, el cual retoma el pasaje del Evangelio de Lucas donde se narra el anuncio del nacimiento de Cristo a los pastores (Lc 2, 13-14), pero reinterpretándolo como un coro angélico: "También unos pastores afirmaban haber visto al filo

\footnotetext{
8 ÁLVAREZ, Rosario, "Iconografía musical y organología: un estado de la cuestión”, en Revista de Musicología, 20, nº 2, 1997, pp. 767-782.

9 Una de las primeras aportaciones para catalogar imágenes musicales desde un punto de vista iconográfico la hallamos en MAYER BROWN, Howard y LASCELLE, Joan Brown, Musical iconography: A manual for cataloguing musical subjects in Western art before 1800, Cambridge, Harvard University Press, 1972.

${ }_{10}$ Para la cronología, vid. SANTOS OTERO, Aurelio de, Los evangelios apócrifos, Madrid, Biblioteca de Autores Cristianos, 1996 (1956), p. 171.
} 
de la media noche algunos ángeles que cantaban himnos y bendecían con alabanzas al Dios del cielo" (Ps Mt. 13, 6) ${ }^{11}$.

No obstante, cabe decir que el verbo que aparece en el texto latino no es cantar sino la expresión dicere hymnum - traducida aquí como "cantar himnos"- y por lo tanto habría que tomarla con una cierta cautela, ya que tal vez podría estar haciendo referencia al recitado rítmico del texto religioso y no tanto a nuestro actual concepto de canto. Es éste un problema que se hace extensible a la mayoría de las menciones de la música angélica contenidas en los apócrifos. Sin embargo la idea vuelve a repetirse en la Jerarquía Celestial del autor bizantino conocido como el pseudo Dionisio el Aeropagita (s. V-VI) (Dion. Ar. CH 4, 4, 181b), y puesto que unánimemente queda aceptado que los himnos bizantinos tenían un carácter canoro, nos hallamos aquí, sin duda alguna, ante la música de los ángeles. Las primeras imágenes de la natividad (Iconclass 73B13) que incluyen la presencia del coro angélico son de origen bizantino y sintetizan una serie de tradiciones relativas al nacimiento de Cristo que ya habían sido recogidas por los evangelios apócrifos y en especial por el Protoevangelio de Santiago y el Evangelio del Pseudo Mateo, los cuales ejercieron una gran influencia sobre la literatura y las artes visuales del mundo medieval ${ }^{12}$. Su esquema compositivo se difundirá por otras regiones europeas desde finales del siglo VIII sin modificaciones sustanciales, empezando por la península itálica ${ }^{13}$. Un buen ejemplo es la miniatura bizantina que decora a página completa el Evangelario de Nikephoros Phokas (ca. 965, Athos, Biblioteca del monasterio Megisti Lavra, fol. 144v), donde la escena queda presidida por un pequeño grupo de ángeles que, distanciándose levemente de su compañero anunciante, elevan las manos y los ojos hacia las alturas, con las bocas ligeramente entreabiertas. Con el tiempo, el grupo angélico irá ganando independencia dentro de la propia composición, especialmente en lo que al arte alemán se refiere. A mediados del siglo XI ya es posible observar la tendencia de colocarlos sobre el portal, pudiendo aparecer o no los pastores, y en el siglo XII ya ostentan la cartela con la inscripción Gloria in excelsis Deo como ocurre en el Evangelistar de Speyer (ca. 1197, Karlsruhe Badische Landesbibliothek, Codex Bruschal 1 fol. 5v). En algún momento entre los siglos X y XIII estos ángeles debieron convertirse en cantores, aunque existe el problema de su ambigua representación como músicos, ya que sólo a partir de inicios del siglo XIV portarán partituras o instrumentos que los identifiquen como tales, como puede observarse en el Misal de St. Kunibert (inicios del s. XIV, Colonia, Darmstadt Library, Hs. 837, fol. 283) y en el Altenberg Altar (ca. 1340, Frankfurt, Städel Museum). Prácticamente de manera paralela, se desarrolla en territorio italiano la tradición de colocar ángeles músicos sobre el portal en imágenes natalicias que sintetizan el anuncio y la adoración de los pastores, como es el caso

11 Trad. esp. Ibid., p. 204.

12 Ibid., p. 172.

13 STAITI, Nico, Angeli e pastori. L'immagine musicale della Natività e le musiche pastorali natalizie, Bologna, Ut Orpheus Edizioni, 1997, p. 26. 
de la natividad del Políptico de San Pancracio de Bernardo Daddi (mediados del s. XIV, Florencia, Galleria degli Uffizi) (fig. 1). Junto a la tradición de la música angélica existe desde antiguo la de dotar a los pastores de rústicos instrumentos de viento para identificarlos como tales ${ }^{14}$. Nico Staiti ha visto en esta música pastoril la visualización de la música humana, en ciertas ocasiones no exenta de un carácter pecaminoso ${ }^{15}$, por lo tanto cabría interpretar a los ángeles músicos de estas imágenes como su opuesto celestial. Esta proliferación de música angélica en el contexto natalicio a partir del siglo XIV tal vez se deba a la irrupción en Europa de la Leyenda Dorada de Santiago de la Vorágine, compilación hagiográfica de carácter devocional escrita en Génova a mediados del siglo XIII, en cuyos capítulos dedicados a la natividad de Cristo (cap. VI) y a la adoración de los magos (cap. XIV) se vuelven a mencionar los cánticos angélicos, esta vez dotándolos de un claro carácter musical. El éxito y la difusión de este texto explicaría que el coro de ángeles músicos se convierta en un tema muy recurrente en las imágenes natalicias

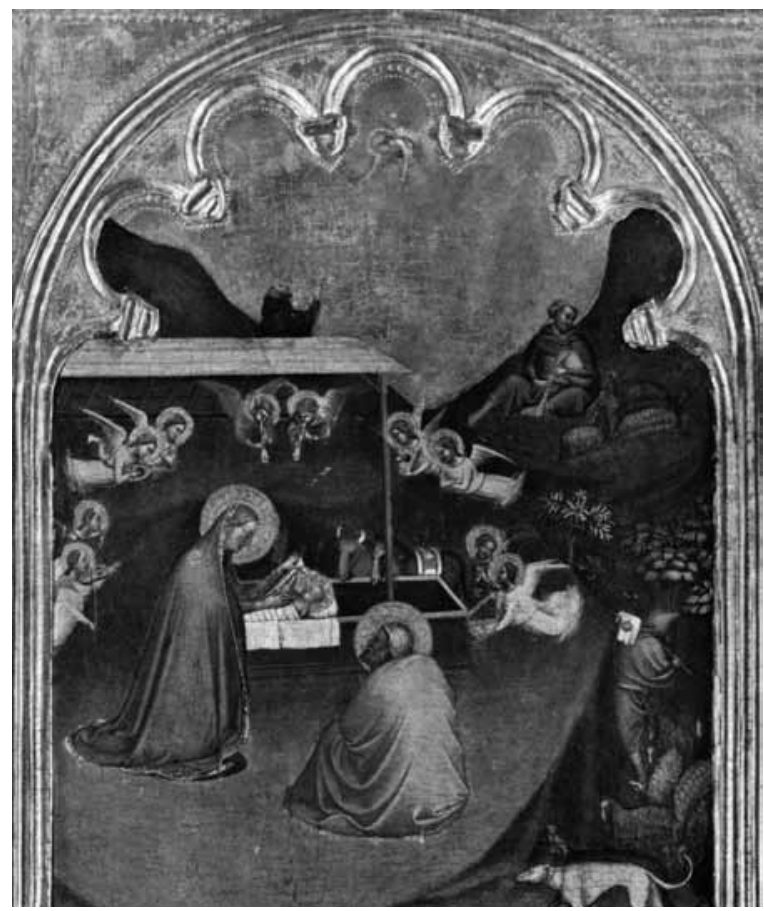

Fig. 1. Bernardo Daddi, Natividad, Políptico de San Pancracio, 1335-1340, temple sobre tabla, 50 × $38 \mathrm{~cm}$., Florencia (Italia), Galleria degli Uffizi, inv. 1890, n. 8345 (1890 post). especialmente a partir del siglo XV, momento en el que se independizan los diversos episodios narrativos que conforman los distintos tipos iconográficos: la adoración de Cristo niño por la Sagrada Familia (Iconclass 73B21) (Iconclass 73B23), la adoración de los pastores (Iconclass 73B25), la adoración de los magos (Iconclass 73B57) $\mathrm{y}$, en un porcentaje mucho menor, el anuncio a los pastores (Iconclass 73B14).

La segunda mención en importancia de la música angélica en los evangelios apócrifos acontece en el contexto de la resurrección de Cristo, o más bien en su anástasis o descenso al limbo, uno de los episodios preferidos por los llamados apócrifos de la pasión y resurrección, de los cuales los más importantes son el EvanPhokas.

14 Esta tradición ya puede observarse en la mencionada miniatura del Evangelario de Nikephoros

15 STAITI, Nico (1997), op. cit., p. 51. 
gelio de Bartolomé (s. IV) ${ }^{16}$ y la parte segunda de las Actas de Pilatos o Descensus Christi ad Inferos (s. V) ${ }^{17}$. Se trata de la entrada triunfante de Cristo en el limbo y la consiguiente liberación de las almas que, encabezadas por Adán, los patriarcas, los profetas y demás progenitores del Antiguo Testamento, son salvadas y conducidas al paraíso entre alabanzas hacia la divinidad y cánticos de alegría donde, en ocasiones, también participan los propios ángeles: "De nuevo dijo Bartolomé: 'También vi a los ángeles que subían delante de Adán y cantaban himnos" (Evangelio de Bartolomé 1, 23) ${ }^{18}$.

A pesar de que el episodio del descenso de Cristo al limbo y la liberación de las almas fue abundantemente representado en la cultura bizantina, no existe ninguna referencia a la música angélica ni, por extensión, a cualquier expresión de música celestial en estas figuraciones. Las razones de esta ausencia serían semejantes a las que se aplicarían al caso de las primeras imágenes narrativas de la natividad: la ambigüedad canora de los ángeles que aparecen en el arte bizantino. Sin embargo, mientras que en las imágenes natalicias se aprecia la voluntad de agrupar a los ángeles en coros, esto no ocurre en las anástasis de área bizantina. En primer lugar, cabría sopesar, como ya se ha mencionado, las posibles diferencias entre el concepto antiguo de canto y el actual. Tal vez ello explicaría porqué en el arte bizantino no existía una tradición de representación inequívoca del ángel músico. En segundo lugar existe la duda razonable de si las fuentes que manejaron los artistas bizantinos, o más bien las autoridades eclesiásticas que idearon los programas visuales a representar, serían las mismas que conservamos en la actualidad o si, más bien, se trataría de otros escritos aunque éstos procedieran de una tradición oral y literaria común. En cuanto a las imágenes del descenso de Cristo a los infiernos realizadas posteriormente en otros ambientes culturales, los artistas debieron tomar como modelo las representaciones bizantinas, sin acudir a las fuentes literarias. Aún así, en el Pasional de la Universidad de Praga se representa a un Cristo de gran tamaño conduciendo las almas al paraíso, quedando la escena enmarcada por una arquitectura gótica con ángeles que tañen sus instrumentos de cuerda (ca. 1320, Cod. XIV A 17, fol. 18r). También cabe destacar un descenso de cronología muy posterior donde sí que se evidencia una clara referencia a los evangelios apócrifos. Se trata del Cristo Abriendo las Puertas del Cielo de Bartolomé Bermejo (ca. 1480, Barcelona, Institut Amatller d'Art Hispànic) donde tres ángeles cantores con vestes litúrgicas sostienen un rollo que deja visible dos tetragramas con notación cuadrada al tiempo que acompañan a las almas que salen del limbo. El cortejo es precedido por Cristo triunfante que señala su crucifixión como prueba de su victoria sobre la muerte (fig. 2).

\footnotetext{
16 Para la cronología vid. SANTOS OTERO, Aurelio de (1996), op. cit., p. 534.

17 Para la cronología vid. Ibid., pp. 393-394.

18 Trad. esp. Ibid., p. 540.
} 


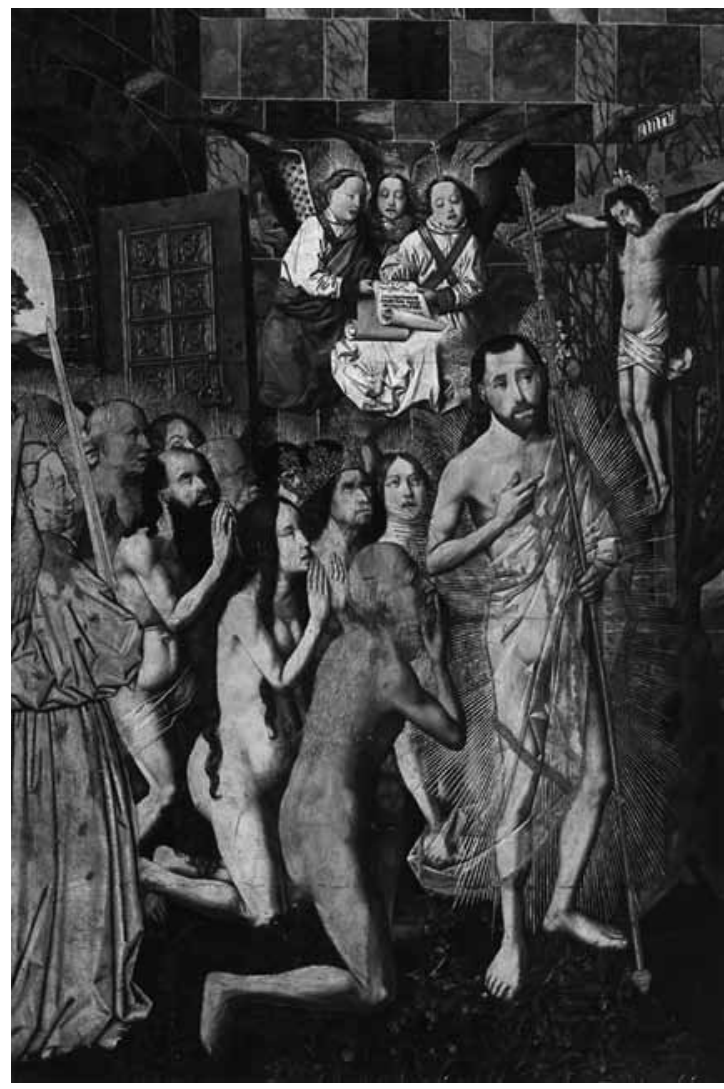

Fig. 2. Bartolomé Bermejo, Cristo abriendo las puertas del cielo, ca. 1480, temple sobre tabla, 103 x $68 \mathrm{~cm}$, Barcelona (España), Institut Amatller d'Art Hispànic, inv. IAAH 546.

Si bien las referencias de la música celestial en la imagen del descenso a los infiernos y la liberación de las almas de los patriarcas, profetas y otros personajes (Iconclass 73D94) son prácticamente nulas, la idea de un ceremonial musical en el momento del triunfo de Cristo sobre la muerte debió pervivir en la cultura eclesiástica $\mathrm{y}$, posteriormente, fue trasladado al episodio canónico de la ascensión. Para entender las posibles razones de esta traslación más allá del hecho de que ambos episodios comparten un movimiento ascensional, cabe tener en cuenta que en Occidente el episodio de la ascensión de Cristo tuvo una fortuna literaria e icónica mucho mayor que su descenso al limbo, tal vez porque resultaba mucho más interesante que la victoria del Redentor contara con testigos presenciales. Así pues, al desaparecer la comitiva de las almas liberadas, los únicos cánticos de alegría que celebrarían el triunfo de Cristo serían los de los ángeles. El hecho de que la ascensión apenas fuera descrita por los evangelios, tanto canónicos (Mc 16, 19; Lc 24, 51; Hch 1, 9-10) como apócrifos (Actas de Pilato I, 16, 6) no debió sino reforzar esta traslación que ya puede observarse a mediados del siglo XIII en la Leyenda Dorada. En ella se menciona que Cristo "Ascendió rodeado de una inmensa multitud de ángeles y llevando consigo un botín de hombres" (Legenda Aurea 72) ${ }^{19}$, lo cual tendría mucho más que ver con la liberación de las almas del limbo que con la ascensión bíblica. Además, ante la cuestión de "cómo ascendió" se añade que lo hizo "Jubilosamente. O sea, con alegría y entre cánticos gozosos de los ángeles" (Legenda Aurea 72) ${ }^{20}$. A tal efecto la Leyenda Dorada cita al propio san Agustín: "Al subir Cristo al cielo, el firmamento entero se sobrecogió, los astros se admira-

\footnotetext{
19 Trad. esp. MACÍAS, José M., La Leyenda Dorada, Madrid, Alianza Forma, 1990 (1982), p. 303.

${ }^{20}$ Trad. esp. Ibid., p. 303.
} 
ron, los ejércitos celestiales le aclamaron uniendo el sonido de sus trompetas a las dulces melodías de los coros de los ángeles [...]" (Legenda Aurea 72) ${ }^{21}$. De esta manera, a partir del siglo XV se observa un cierto interés por dotar a la imagen de la ascensión (Iconclass 73E42) de un ambiente musical como ocurre en el folio 184r de las Muy Ricas Horas del Duque de Berry (hermanos Limbourg, 14111416, Chantilly, Musée Condé, ms 65), ya que bajo la escena aparecen tres ángeles cantores sosteniendo un libro. Otro tanto ocurre con la ascensión de un Libro de Horas de Isabel la Católica que se conserva en la Real Biblioteca del Escorial y su encuadramiento de ángeles músicos (ca. 1469, fol. 72v). Sin embargo, hay que tener en cuenta que, más que al conocimiento de las fuentes literarias, la inclusión de la música celestial en estas imágenes podría deberse a la influencia del tipo de la asunción de la Virgen con ángeles músicos, el cual gozó de una importancia mucho mayor que la ascensión en la literatura y, sobretodo, en las artes visuales. Una de las primeras obras en las que el ángel músico ya aparece totalmente inserto en el tipo de la ascensión es el Cristo glorificado en la corte celeste de Fra Angelico (ca. 1423-1424, Londres, National Gallery), aunque más que de una pintura narrativa podríamos considerarla como una imagen conceptual que recoge en la figura de Cristo la tradición iconográfica del tema del anástasis. Los instrumentos tañidos por los ángeles son en su mayoría de música baja o de escasa potencia sonora, pero también destacan, por su posición central, el órgano - instrumento sacro por excelencia ${ }^{22}$ - y las grandes trompetas rectas que suelen ser recurrentes en la imagen de la asunción y coronación de la Virgen pero que también podrían remitir a la cita de san Agustín contenida en la Leyenda Dorada.

El tipo iconográfico de la ascensión con ángeles músicos conoce su mayor difusión hacia finales del siglo XV y durante el siglo XVI en la península itálica, siguiendo los esquemas compositivos ofrecidos por la imagen de la asunción de la Virgen. Así, cuando los artistas próximos a las obras de embellecimiento del palacio papal doten de instrumentos de música baja a la asunción, las representaciones de la ascensión con ángeles músicos recibirán igual tratamiento. Buenos ejemplos de ello son la ascensión con san Luis de Tolousse, san Bernardo de Claraval y san Antonio de Padua de Pinturicchio (1486, Roma, Santa Maria di Aracoeli, capella Bufalini) y la Ascensión de Cristo del Perugino (1495-1498, Lyon, Musée Municipal des Beaux-Arts) (fig. 3).

El episodio de la narración evangélica más abundante en referencias musicales es, sin duda alguna, el tránsito de la Virgen María. Los hechos que lo conforman son narrados con todo detalle en el extenso elenco de apócrifos asuncionistas conservados hasta la actualidad, siendo los más importantes el Libro de San Juan

\footnotetext{
21 Trad. esp. Ibid., p. 303.

22 Hasta inicios del siglo XVII, la única música litúrgica unánimemente aceptada por la Iglesia fue el canto con el ocasional acompañamiento de órgano.
} 


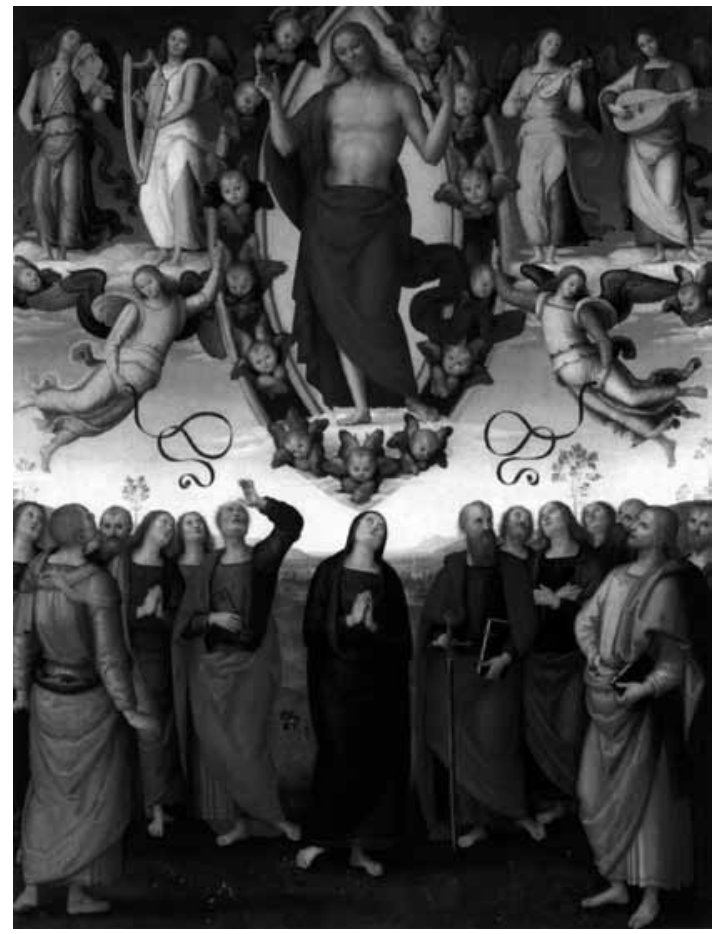

Fig. 3. Pietro di Cristoforo Vanucci llamado "il Perugino", Ascensión de Cristo, 1495-1498, óleo sobre tabla transferido a lienzo, 325 x $265 \mathrm{~cm}$., Lyon (Francia), Musée Municipal des Beaux-Arts, inv. A 134.

Evangelista (el Teólogo) (s. IV) ${ }^{23}$, el Libro de Juan Arzobispo de Tesalónica (s. IV-V) ${ }^{24}$ y la Narración del Pseudo José de Arimatea (posterior a éstos dos) ${ }^{25}$. En todos ellos la música humana y celestial, siempre cantada, cumple un importante papel en el homenaje realizado a la Virgen María en el momento de su muerte y la ascensión de su alma, en su procesión fúnebre $\mathrm{y}$, finalmente, en la ceremonia de acogida de su cuerpo en el paraíso celeste. Resulta significativo que, conforme se avanza en el tiempo, el número de menciones de la música celestial aumente en el relato. Los cánticos angélicos se hallan ligados desde un principio a la assumptio animae, y por ello la primera vez que aparecen lo hacen en boca del ángel que anuncia a la Virgen su muerte: "¿Qué es lo que tienes, señora? Has de saber que, cuando envíe por ti el Señor, no vendré yo solo, sino que acudirán también los ejércitos angélicos e irán cantando ante ti" (Libro de Juan arz. de Tesalónica 3) ${ }^{26}$. Así pues, María en su lecho de muerte no sólo recibe los cantos de los apóstoles que la acompañan y los del resto de fieles que esperan fuera de la estancia, sino que, a la orden del propio Cristo, los coros celestiales también participan en la salmodia fúnebre:

"Y he aquí que (de repente) se presenta el Señor sobre las nubes con una multitud sin número de ángeles. Y Jesús en persona, acompañado de Miguel, entró en la cámara donde estaba María, mientras que los ángeles y los que por fuera rodeaban la estancia cantaban himnos" (Libro de Juan arz. de Tesalónica 12) ${ }^{27}$.

"Volvióse entonces el Señor y dijo a Pedro: 'Ha llegado la hora de dar comienzo a la salmodia'. Y, entonando Pedro, todas las potencias celestiales respondieron el 'Aleluya'.

\footnotetext{
23 Para la cronología vid. SANTOS OTERO, Aurelio de (1996), op. cit., p. 574.

24 Para la cronología vid. Ibid., p. 602.

25 Para la cronología vid. Ibid., p. 640.

26 Trad. esp. Ibid., p. 611.

27 Trad. esp. Ibid., p. 630.
} 
[...] Y el Señor, después de extender sus puras manos, recibió su alma santa e inmaculada." (Libro de S. Juan Evangelista 44) ${ }^{28}$.

La assumptio animae o dormición de la Virgen (Iconclass 73E741) fue abundantemente representada durante la Edad Media, incluyendo en algunos casos la música angélica. Una de las más tempranas y fieles a la narración apócrifa es la del Hunterian Psalter (ca. 1170, Glasgow, Biblioteca de la Universidad, Sp Coll MS Hunter U.3.2 (229), fol. 18r), pudiéndose apreciar ya un interés por agrupar a los ángeles en un coro que se aproxima a la cabecera del lecho mortuorio, mientras que en el registro inferior se representa la procesión fúnebre donde la presencia de los ángeles también podría remitir al ceremonial angélico-musical en el que se desarrollan las exequias: «Se levantaron, pues, los apóstoles y cargaron con el féretro de María. Pedro, mientras tanto entonó: 'Salió Israel de Egipto [Ps 113, 1]. Aleluya'. El Señor y los ángeles, por su parte, se paseaban sobre las nubes y cantaban himnos y alabanzas sin ser vistos. Solamente se percibía la voz de los ángeles.» (Libro de Juan arz. de Tesalónica 13) ${ }^{29}$. Al igual que en el caso de la natividad, habrá que esperar hasta el siglo XIV para que los ángeles sean dotados, claramente, de un carácter musical mediante instrumentos y música escrita. A ello contribuyó enormemente la Leyenda Dorada en su capítulo dedicado a la asunción de la Virgen (cap. CXIX) donde, sin dejar de remitirse a los apócrifos, las menciones de la música angélica resultan mucho más numerosas y explícitas. Incluso el momento de la assumptio animae es ya descrita en un inequívoco ambiente de música celestial:

"Cristo, con el alma de su Madre en los brazos, emprendió su viaje a la gloria rodeado de $[\ldots]$ multitud de mártires $[\ldots]$ ángeles $[\ldots]$ confesores $[\ldots]$ vírgenes que le daban escolta. Quienes habían quedado en el cielo, al oír los cánticos de los que a él subían, llenos de admiración salieron al encuentro de aquella solemnísima procesión [...]." (Legenda Aurea 119$)^{30}$.

Probablemente, una de las primeras — si no la primera - imágenes de la dormición que incluyen la figura del ángel ya claramente representado como músico sea el fresco de La Muerte de la Virgen de Giovanni y Pietro da Rimini para la Iglesia de Santa Maria in Porto Fuori de Rávena (primer tercio del s. XIV), donde la figura de Cristo acogiendo el alma de su madre queda flanqueada por ángeles instrumentistas y personajes masculinos barbados — probablemente profetas - con libros abiertos que parecen interpretar música vocal. Sin embargo, las imágenes de la dormición con ángeles músicos nunca fueron abundantes y comienzan a escasear especialmente a partir del siglo XVI, momento en el que fueron prácticamente sustituidas por otros dos tipos en los que la inclusión de la música angélica sí que resulta muy recurrente: la asunción (Iconclass 73E77) y la coronación de la Virgen (Iconclass 73E79).

\footnotetext{
28 Trad. esp. Ibid., p. 596.

29 Trad. esp. Ibid., p. 633.

30 Trad. esp. MACÍAS, José M. (1990), op. cit., p. 479.
} 
La assumptio corporis ya es descrita someramente en los evangelios apócrifos, donde se subraya el carácter milagroso del hecho al rodearlo de perfumes exquisitos, resplandores sobrenaturales, voces angélicas y música celestial:

"[...] por tres días consecutivos se oyeron voces de ángeles invisibles que alababan a su Hijo, Cristo nuestro Dios. Más, cuando concluyó el tercer día, dejaron de oírse las voces, por lo que todos cayeron en la cuenta de que su venerable e inmaculado cuerpo había sido trasladado al paraíso. [...] vimos de pronto a Isabel [...] y a Ana, y a Abraham, a Jacob y a David que cantaban el 'Aleluya'. Y vimos también a todos los coros de los santos que adoraban la venerable reliquia de la madre del Señor. Se nos presentó también un lugar radiante de luz [...]. Y el sitio donde tuvo lugar la traslación de su santo y venerable cuerpo [...] estaba saturado de perfume. Y se dejó oír la melodía de los que cantaban himnos a su Hijo [...]" (Libro de S. Juan Evangelista 48-49) ${ }^{31}$.

Aún así, para encontrar la presencia explícita de los cánticos angélicos cabe remitirse a la Leyenda Dorada, donde se menciona como éstos habrían acompañado el traslado del cuerpo de la Virgen al paraíso:

"En las revelaciones de santa Isabel se lee el caso siguiente: [...] estando la santa en éxtasis, vio [...] un sepulcro resplandeciente [...] en cuyo interior yacía, rodeado de infinidad de ángeles, el cadáver de una mujer. Poco después los espíritus angélicos, tomaron en sus manos el cuerpo [...] lo resucitaron y, dándole escolta, comenzaron a subirlo al cielo. Antes de que llegaran a desaparecer pudo advertir que un hombre admirable y glorioso [...] enarbolando en sus manos una cruz a modo de estandarte, y acompañado de millares y millares de ángeles, salía al encuentro del cortejo y [...] formando una sola comitiva comenzaron a cantar jubilosamente, y todos juntos reemprendieron la marcha ascendente a la gloria [...]" (Legenda Aurea 119) ${ }^{32}$.

En el folio $19 \mathrm{v}$ del ya citado Hunterian Psalter puede observarse en una curiosa representación de la asunción el importante papel que cumplen los ángeles en este episodio. Pero el gran florecimiento de las imágenes de la Virgen asunta rodeada de ángeles músicos se dará en territorio toscano a partir de las primeras décadas del siglo XIV. Una de sus primeras expresiones es La Virgen de la Asunción pintada por Niccolò di Ser Sozzo en el códice llamado Caleffo Bianco o dell'Assunta (1336-1338, Siena, Archivio di Stato, Palazzo Piccolomini). En concreto, el episodio representado corresponde a una tradición contemplada en la Narración del Pseudo José de Arimatea, donde la Virgen lanza su cinto al apóstol Tomás como prueba del milagro (Iconclass 73E772). Sin embargo la música angélica se halla totalmente ausente en el texto mencionado, por lo que su presencia en el relieve debería responder al conocimiento de otros apócrifos, a la Leyenda Dorada, o bien

\footnotetext{
31 Trad. esp. SANTOS OTERO, Aurelio de (1996), op. cit., p. 598-599.

32 Trad. esp. MACÍAS, José M. (1990), op. cit., p. 482.
} 
a la existencia de otras tradiciones de carácter oral. Aunque resulta difícil conocer el peso real de esta miniatura, lo cierto es que por aquel entonces comenzaron a surgir, tanto en pintura como en escultura, una gran cantidad de imágenes similares entre las que destaca el altorrelieve realizado por Niccolò di Cecco del Mercia y su hijo para el púlpito de la Catedral de Prato (ca. 1360, Prato, Museo dell'opera del Duomo) (fig. 4). Obras posteriores como las escenas de la vida de la Virgen

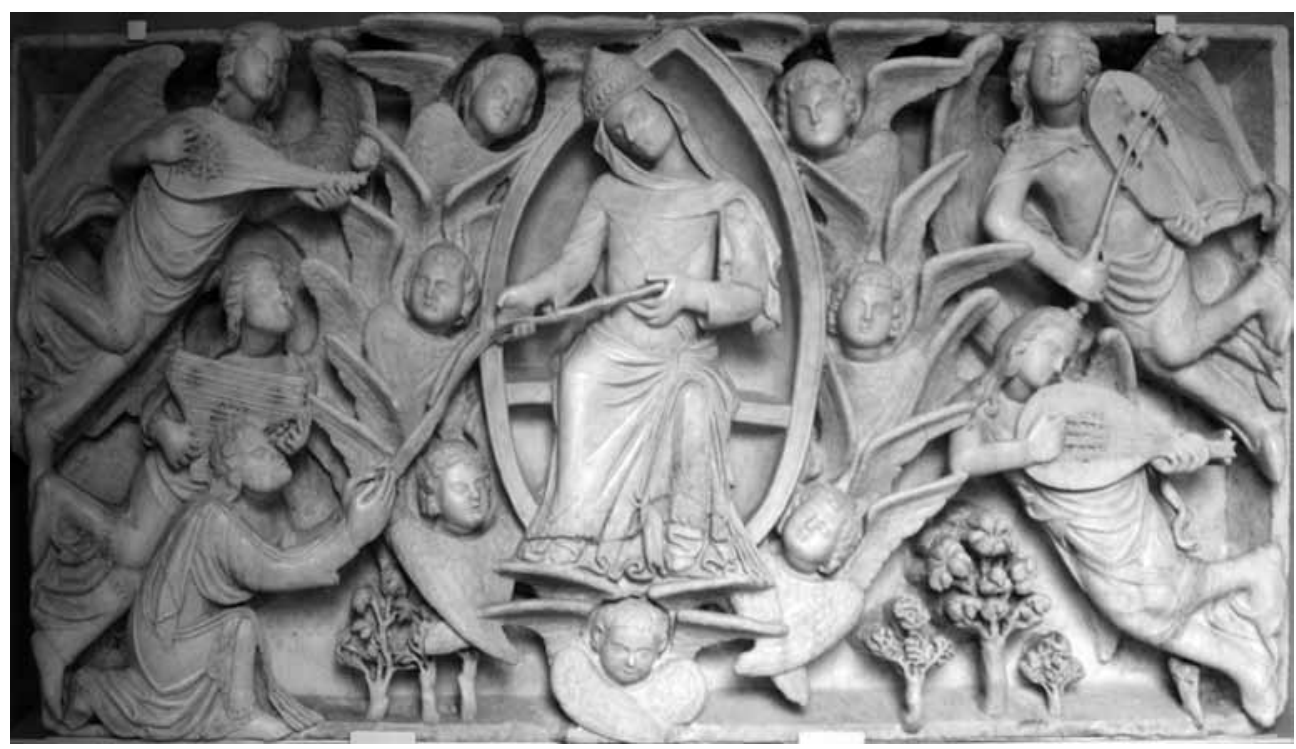

Fig. 4. Niccolò di Cecco del Mercia y Sano di Niccolò di Cecco, La Virgen asunta entrega su cinto a san Tomás, ca. 1360, mármol, Prato (Italia), Museo dell'Opera del Duomo.

que decoran la portada sur de la Catedral de Augsburgo (1377) y La Asunción de la Virgen de Matteo di Giovanni (ca. 1474, Londres, National Gallery) demuestran la difusión y el éxito alcanzado por este tipo durante los siglos XIV, XV y XVI, no sólo en la península italiana sino también en toda el área europea.

No obstante, puede que la coronación de la Virgen sea la imagen de la narración evangélica que con mayor frecuencia incluye la figura del ángel músico. Las referencias a este tema son escasas, ya que los evangelios apócrifos se limitan a señalar la glorificación que obtuvo María en los cielos una vez ascendida (Libro de S. Juan Evangelista 48-49). El tema de la coronación se trataría más bien de un concepto piadoso surgido a raíz de la interpretación de ciertos elementos que sería asumido primero por la élite intelectual eclesiástica ${ }^{33}$ y entraría posteriormente a

33 AZCÁRATE DE LUXÁN, Matilde, "La coronación de la Virgen en la escultura de los tímpanos góticos españoles" en Anales de la Historia del Arte, 4, 1993-1994, pp. 353-363. Cita como responsables de la configuración del concepto de María como Regina Coeli a san Epifanio (315-403), san Gregorio de Tours 
formar parte de la tradición cultural convencionalizada gracias al papel difusor de la literatura devocional y las artes visuales. Tal vez en la Narración del Pseudo José de Arimatea pueda ya vislumbrarse el germen del elemento más importante, la corona, puesto que se narra como la assumptio animae ocurre en medio de los himnos del Cantar de los Cantares, entonados por los ángeles (Narración del Pseudo José de Arimatea 11-12). El Cantar de los Cantares es una colección de cantos eróticos que celebran el amor entre el esposo y la esposa datado en torno al siglo IV que forma parte de la Biblia canónica. Desde muy antiguo el poema fue interpretado como las bodas místicas de la divinidad con el pueblo escogido y san Bernardo (1090-1153) en sus sermones llegó a comparar a la joven esposa del Cantar con la Virgen María. Sin embargo, el asunto de la coronación brilla por su ausencia tanto en el poema bíblico como en los evangelios apócrifos. La primera vez que la hallamos es en la Leyenda Dorada, donde, al describir los cánticos del Cantar de los Cantares que se interpretan en la assumptio animae de María, se añade al verso "Ven desde el Líbano esposa mía" $(\mathrm{Ct} 4,8)$ la frase "Ven desde el Líbano, que vas a ser coronada" (Legenda Aurea 119). Seguramente, este añadido esté haciendo referencia a una tradición cultural ya inserta en ámbito eclesiástico a través de la liturgia, el teatro religioso, y/o las ceremonias de profesión de las jóvenes novicias ${ }^{34}$. El tipo más antiguo de la coronación corresponde a la Virgen siendo coronada por Cristo (Iconclass 73E792) y puede que una de las primeras imágenes donde se lo dota de música celestial sea una B miniada del Salterio de la reina Margarita de Noruega (primera mitad del s. XIII, Berlín, Kupferstichkabinett, Hs. 18 A 8, fol. 14v), si bien en este caso la música es interpretada por el Rey David tañendo su arpa y un personaje sin identificar que le acompaña haciendo sonar un cordófono frotado con arco. Habrá que esperar al siglo XIV para que aparezcan los ángeles músicos. Así ocurre por ejemplo en la coronación que culmina la dormición y la asunción de una Biblia Vulgata parisina datada hacia el 1310-1320 (Berlín, Kupferstichkabinett, Hs. 78 E 2, fol. 2), en las portadas de la Catedral de Vitoria (1301-1325) y de la de Augsburgo (1377) y en el fresco de la coronación de María de la Torhalle de la Abadía de Lorsch. Pero el gran éxito de esta imagen viene dado por la pintura sobre tabla, empezando tal vez por el Altenberg Altar en territorio alemán (ca. 1340, Frankfurt, Städel Museum) y el Políptico Baroncelli de Giotto en la península itálica (ca. 1334-1337, Florencia, Basílica de Santa Croce). Se trata además de imágenes donde el tipo ya se enriquece con los grandes instrumentos de viento metal propios de la música heráldica. Este recurso será empleado en la gran mayoría de las representaciones de la coronación hasta inicios del siglo XVI, mo-

(†1593), san Juan Damasceno (muerto en el 760) y especialmente a San Bernardo (1090-1153), a san Alberto Magno (1206-1280) con su Laudibus Beatae Mariae y a san Buenaventura (1221-1274) a quien se atribuye el Speculum Beatae Mariae.

${ }^{34}$ El canto litúrgico de la misa de profesión de fe de las novicias comprendía la frase "Veni sponsa Christi / accipe coronam quam tibi Dominus preparavit in aeternum". Vid. KENDRICK, Robert L., Celestial Sirens. Nuns and their music in Early Modern Milan, Oxford, Clarendon Press, p. 134. 
mento en el que los instrumentos de música baja recuperan su protagonismo, como sucede en la Coronación de la Virgen realizada por Pinturicchio para la Iglesia del Convento Santa Maria dei Minori di Umbertide, cerca de Perugia (1503, Roma, Pinacoteca Vaticana). A partir de mediados del siglo XVI, la imagen preferida de la coronación responderá al tipo de la Virgen coronada por la Trinidad (Iconclass 73E793). Éste parece haberse originado en territorio alemán y flamenco, siendo uno de los primeros ejemplos la Coronación de la Virgen del Maestro de la Vida de María (ca. 1460, Munich, Alte Pinakothek) (fig. 5).

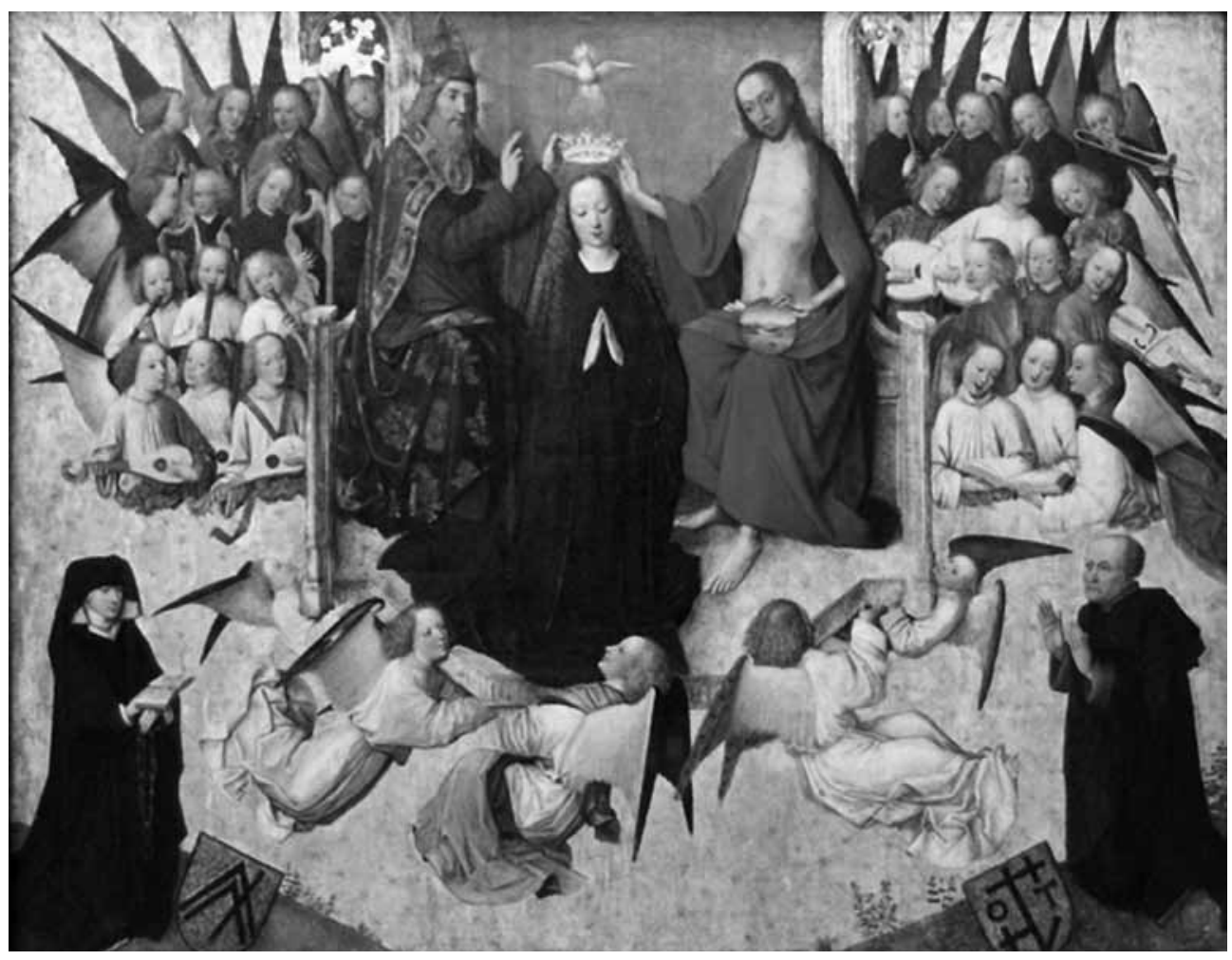

Fig. 5. Maestro de la Vida de María, Coronación de la Virgen, ca. 1460, óleo sobre tabla, 83 x 108 cm., Munich (Alemania), Alte Pinakothek, Inv.-Nr. WAF 624.

Como puede observarse, los evangelios apócrifos resultan claves tanto para la configuración del ángel músico como para su inclusión en los episodios de la narración evangélica que hemos analizado brevemente en este artículo ${ }^{35}$. Ello no sig-

35 Cabría añadir la imagen de la anunciación de la Virgen (Iconclass 73A5) con sus diversos tipos iconográficos. La música angélica en el contexto de la anunciación aparece en el llamado Evangelio armenio de la infancia (s. VI), un apócrifo algo más tardío que no contó con tanta difusión como el resto. Sin embargo, 
nifica poder asegurar que los ángeles que aparecen interpretando himnos en estos textos tengan siempre un carácter musical, y, en todo caso se trataría de música meramente vocal. Sin embargo, estos fragmentos debieron dar lugar a una serie de tradiciones en las que se dotaba claramente de una actividad canora a estos ángeles y que posteriormente serían recogidas por la literatura y las artes visuales, primero en la miniatura y, algo más tarde, en el arte monumental de los templos y en la pintura sobre tabla. La manera más sencilla de representar a los ángeles como músicos debió de ser colocar en sus manos instrumentos musicales. Sólo a partir de las primeras décadas del siglo XIV los angélicos intérpretes sostienen folios, libros o rollos de música escrita que los identifican como cantores. Por otra parte, no sería extraño que estas imágenes con ángeles músicos — especialmente las de la natividad de Cristo y las del tránsito de la Virgen - llegaran a formar parte de la memoria visual colectiva e influyeran a su vez en otros tipos de la narración evangélica en los que nunca antes se había incluido la música angélica como es el caso del nacimiento de María (Iconclass 713A31), la educación de la Virgen (Iconclass 73A3), los desposorios de la Virgen (Iconclass 73A42), la presentación de Cristo en el templo y su circuncisión (Iconclass 73B3; Iconclass 73B4), el descanso en la huida a Egipto (Iconclass 73B65) y el bautismo de Cristo (Iconclass 73C121).

en el arte visual la inclusión del ángel músico en este episodio parece responder más a las especulaciones teológico-musicales de autores/as eclesiásticos/as como Hildegard von Bingen (1098-1179). Vid. PERPIÑÁ GARCÍA, Candela, "Los ángeles músicos en el tipo iconográfico de la Anunciación", en Emblemática trascendente. Hermenéutica de la imagen, iconología del texto, Actas del VII Congreso Internacional de Emblemática (Pamplona, 9-11 de diciembre de 2009), de próxima publicación. 